\title{
REPENSANDO O PAPEL DO ADVOGADO-GERAL DA UNIÃO NO CONTROLE DE CONSTITUCIONALIDADE: APROXIMAÇÕES TEÓRICAS
}

\author{
BRENO BAÍA MAGALHÃES ${ }^{1}$
}

\begin{abstract}
RESUMO: O Supremo Tribunal Federal decidiu que o Advogado-Geral da União não está jungido à defesa de atos que considere inconstitucionais, especialmente, se já houver manifestação da Corte Suprema nesse sentido ou quando se tratarem de atos que se põem contra interesse da União. Nesse sentido, o Advogado-Geral da União exerceria um direito de manifestação nas Ações Diretas de Inconstitucionalidade. A análise teórica dos votos dos ministros nos permite observar quais justificativas são as mais plausíveis para a interpretação das normas constitucionais. Nesse sentido, devemos considerar que a feição política do papel desempenhado pelo Advogado-Geral da União no Governo Federal impede que exerça posição contraditória com a finalidade institucional que Ihe reserva a Constituição Federal.
\end{abstract}

PALAVRAS-CHAVE: Controle Concentrado de Constitucionalidade; AdvogadoGeral da União; Interpretação Constitucional.

ABSTRACT: The Brazilian Supreme Court ruled that the Union's Attorney General is not obligated to defend statutes it deems unconstitutional, especially with prior manifestation of the Supreme Court to do so or when dealing with acts that are against Union's interest. Therefore, the Union's Attorney General would have a right to manifestation in the Direct Actions of Unconstitutionality. A theoretical analysis of the justices opinions allows us to see which are the most plausible justifications for the interpretation of the constitutional norms Accordingly, we must consider that the feature of the political role of the Union's Attorney General in the Federal Government prevents conflicts with the institutional position brought by the Constitution.

KEYWORDS: Control Concentrate Constitutionality; Union's Attorney General; Constitutional Interpretation.

SUMÁRIO: Introdução; 1 Breves Considerações acerca da Advocacia-Geral da União na Constituição de 1988; 2 A Redefinição do Papel do Advogado-Geral da União no Controle Concentrado; 3 Análise Teórica dos Votos da QO na ADI 3.916/DF; Considerações Conclusivas; Bibliografia.

Artigo recebido em 05.08.2011. Pareceres emitidos em 28.10.2011, 31.01.2012 e 12.03.2012. Artigo aceito para publicação em 17.06.2012.

${ }^{1}$ Mestre e Doutorando em Direito pela Universidade Federal do Pará (UFPA). Professor da Faculdade de Belém (FABEL). Bolsista CAPES. brenows@yahoo.com.br 
SUMMARY: Introduction; 1 A Brief Discussion about the Attorney General's Office in the 1988 Constitution; 2 Redefining The Role of the Attorney General's Office in the Judicial Review; 3 Theoretical Analysis of the Justices Opinions of the ADI 3.916/DF; Concluding Considerations; Bibliography.

\section{INTRODUÇÃO: Breve escorço histórico do controle concentrado de constitucionalidade no Brasil.}

A Constituição é nossa lei maior, pois carrega em seu bojo normas que fundamentam todo o ordenamento jurídico, bem como impõe limitações ao poder estatal e consagra direitos fundamentais. Em razão de sua elevada importância para o funcionamento do Estado, são necessários mecanismos que garantam sua perfeita higidez.

O mais importante mecanismo de proteção das normas constitucionais é, sem dúvida, o controle de constitucionalidade das leis. No Brasil, existem várias formas de se controlar a constitucionalidade das leis e demais atos normativos do poder público, como, por exemplo: o controle preventivo feito por meio do veto presidencial e das comissões congressuais de Constituição e Justiça; o controle difuso, exercido por todos os órgãos do poder judiciário e, por fim, o controle concentrado de constitucionalidade ${ }^{2}$, os últimos, por sua vez, inclusos no chamado controle repressivo ou jurisdicional ${ }^{3}$ de constitucionalidade $^{4}$. Em razão do escopo do trabalho, nos focaremos, somente, no controle concentrado de constitucionalidade ${ }^{5}$.

No Brasil, o controle concentrado encontra suas raízes remotas na Constituição de $1934^{6}$. Nesta Constituição, foi estabelecido, também, que cada Estado-Membro poderia elaborar suas Constituições e suas leis, com a devida observância aos princípios da Constituição Federal, em especial,

\footnotetext{
${ }^{2}$ VELOSO, Zeno. Controle Jurisdicional de Constitucionalidade. 3. ed., Belo Horizonte: Del Rey, 2003.

${ }^{3} \mathrm{O}$ controle judicial diz respeito apenas ao controle exercido pelos órgãos judiciários, no exercício de uma função jurisdicional; se contrapondo, de acordo com Cappelletti, ao controle político da constitucionalidade das leis (CAPPELLETTI, Mauro. O Controle Judicial de Constitucionalidade das Leis no Direito Comparado. Porto Alegre: SAFE, 1992, p. 26).

${ }_{5}^{4}$ MORAES, Alexandre de. Direito Constitucional. 18. ed., São Paulo: Atlas, 2005, p. 636-957.

5 A utilização da classificação binária "difuso/concentrado" se justifica, nesse momento, por motivos, meramente, didáticos. Em verdade, compreendemos que as classificações dicotômicas (difuso/concentrado; abstrato/concreto) ou cumulativas (controle "misto") perderam sua capacidade analítica, dada a diversidade e singularidade com que os modelos originais (norte-americano e europeu) se desenvolveram nas tradições jurídicas dos países que os recepcionaram, porquanto a hibridação daqueles modelos tornou inócua qualquer tentativa de separar seus elementos característicos, portanto, a análise de um modelo de justiça constitucional deverá assumir uma feição holística, dando conta de outras variáveis que influenciam na diferenciação dos sistemas nas experiências dos países. Nesse sentido, Cf. MAGALHÃES, Breno Baía. Em Defesa da Convergência dos Sistemas de Controle de Constitucionalidade: aspectos materiais. Revista de Direito Constitucional e Internacional, v. 79, 2012, p. 215.

${ }^{6}$ Esta Carta Política trouxe inúmeras mudanças no controle de constitucionalidade nacional, tais como: a reserva de plenário (art. 179) e a resolução suspensiva do Senado (art. 91, IV e art. 96).
} 
aos chamados "princípios constitucionais sensíveis"7. Desta forma, caso uma lei ou ato normativo estadual violasse tais princípios, poderia o Procurador-Geral da República provocar o Supremo Tribunal Federal para que examinasse a constitucionalidade da lei que determinava a amplitude e duração da intervenção federal, ou seja, o julgamento da constitucionalidade da lei era pressuposto para a decretação da ação interventiva ${ }^{8}$, como afirma Lenio Streck ${ }^{9}$.

Em razão das discussões teóricas e jurisprudenciais em torno da natureza da representação interventiva e a necessidade do regime de exceção em criar um meio de controle concentrado de normas na Constituição de $1946^{10}$, o Procurador-Geral da República foi municiado com uma ação mais expedita e eficaz para infirmar as normas consideradas inconstitucionais ${ }^{11}$. Dessa forma, a partir da Emenda Constitucional n 16, de 26 de novembro de 1965, foi criada, na Constituição de $1946^{12}$, a representação de inconstitucionalidade que, diferentemente da representação interventiva, não necessitava de um conflito entre União e Estado-Membro e posterior decretação de intervenção federal para a fiscalização de constitucionalidade, mas, tão somente a aferição abstrata da possível inconstitucionalidade de uma norma (art. 101, da CF/46)

A Constituição de 1967 trouxe uma importante inovação no controle concentrado, a partir da Emenda Constitucional $n^{\circ} 07$ de $1977^{13}$. Esta emenda acrescentou, dentre as competências originárias do STF, a possibilidade

${ }^{7}$ De acordo com José Afonso da Silva, os princípios constitucionais sensíveis são aqueles que, como o próprio nome denuncia, estão expostos claramente aos sentidos. Sua sensibilidade, prossegue o autor, traz como consequência medidas enérgicas no caso de sua inobservância, como, por exemplo, a intervenção federal (SILVA, José Afonso da. Curso de Direito Constitucional Positivo. 26. ed., São Paulo: Malheiros, 2006, p. 612).

8 Para maiores detalhes, Cf. LEWANDOWSKI, Enrique Ricardo. Pressupostos Materiais e Formais da Intervenção Federal no Brasil. São Paulo: Saraiva, 1994.

${ }^{9}$ STRECK, Lenio Luis. Jurisdição Constitucional e Hermenêutica. Rio de Janeiro: Forense, 2002, p. 348.

10 Não obstante o avanço da representação interventiva na Constituição de 1946 (que, diferentemente, da representação da Constituição anterior, atribuía ao STF a fiscalização direta do ato ou lei, supostamente, violadores dos princípios constitucionais sensíveis), não se tratava de controle abstrato propriamente dito, em razão dos efeitos da declaração da inconstitucionalidade, que se limitava ao litígio federativo, como pontua Zeno Veloso, op. cit., p. 32.

${ }_{11}$ POLETTI, Ronaldo Rebello de Britto. Controle da Constitucionalidade das Leis. 2. ed., Rio de Janeiro: Forense, 1995, p. 85.

12 Lenio Streck, op. cit., p. 354, ressalta os aspectos políticos que motivaram a promulgação da referida Emenda $n^{\circ} 16 / 65$, pois o governo militar necessitava dispor de mecanismos rápidos e eficazes para decidir sobre a constitucionalidade de uma lei estadual, bem como obstaculizar o controle difuso de constitucionalidade. Esta questão se evidencia ainda mais, de acordo com o autor, pelo fato de que o Procurador-Geral da República, além de ser o único legitimado ativo para propor a ação, era livremente nomeado e destituído pelo Presidente da República.

${ }^{13}$ Cumpre ressaltar que esta emenda introduziu, pela primeira vez no direito brasileiro, a ideia de efeito vinculante, pois o art. 187 do Regimento Interno do Supremo Tribunal Federal, visando regulamentar a recém-criada representação interpretativa, dispunha que, a partir da data da publicação da ementa do acórdão no Diário Oficial da União, a interpretação nele fixada teria força vinculante. 
de representação sobre a interpretação de lei ou ato normativo federal ou estadual e a concessão de cautelares nestas mesmas representações (art. 119, I da CF/67).

A Constituição Federal de 05 de outubro de 1988, por sua vez, introduziu enormes mudanças no controle concentrado de normas. A principal, e mais importante, a ser observada diz respeito ao aumento do número de legitimados a propor a ADI. Anteriormente restrita ao PGR, a propositura da ADI foi estendida a um número mais alargado de legitimados ${ }^{14}$, atribuindo maior participação popular no controle de constitucionalidade das leis ${ }^{15}$. Outrossim, a Constituição de 1988 criou novas ações aptas à promover o controle abstrato de normas exercido de forma concentrada pelo STF, são elas: a Ação Declaratória de Constitucionalidade (após a EC nº de 93), Arguição de Descumprimento de Preceito Fundamental e a ADI por omissão.

Concluindo esta breve apresentação, outra importante inovação da Carta Magna de 1988 diz respeito ao papel que desempenha o Advogado-Geral da União na fiscalização abstrata de constitucionalidade, em especial sua citação para defender o ato impugnado como inconstitucional em ADI. Os Ministros do STF discordam quanto à interpretação que deve ser atribuída ao referido dispositivo constitucional, tendo em vista sua aparente clareza semântica. Por meio da análise dos argumentos trazidos nos votos dos juízes constitucionais acerca do tema, discorreremos quais as teorias interpretativas que podem ser extraídas de seus posicionamentos e qual delas seria a mais coerente com a sistemática constitucional de nosso controle de constitucionalidade, uma vez que suas fundamentações são importantes para a delimitação constitucional do papel institucional desempenhado pelo AGU no controle de constitucionalidade.

\footnotetext{
${ }^{14}$ Ainda que não outorgada para qualquer cidadão considerado individualmente, a abertura da legitimidade para propor as ações diretas às entidades e órgãos privados é tão ampla, que é impossível delimitar quem são e quem serão, numericamente, os legitimados a propô-las, conforme o salientado por Gilmar Mendes (MENDES, Gilmar. Jurisdição Constitucional. 5. ed., São Paulo: Saraiva, 2005, p. 155).

${ }^{15}$ Não obstante o caráter objetivo do processo constitucional de controle de constitucionalidade, ou seja, não existem partes ou interesses particulares a serem tutelados, o STF limitou a possibilidade de interposição de $A D I$ e ADC (consecutivamente à ADPF) para determinados legitimados. O Tribunal exige a chamada "pertinência temática" aos legitimados especiais (os Governadores dos Estados e do Distrito Federal, Mesa da Assembleia Legislativa ou da Câmara Legislativa do Distrito Federal, Confederação Sindical ou entidade de classe de âmbito nacional. Como exemplo, cite-se o julgado ADI-MC 305/RN, DJ 06.05.1994, Rel. Paulo Brossard. Gilmar Mendes (Ibid., p. 174) se posiciona abertamente contra a pertinência temática, na medida em que pode se configurar, em verdade, como uma condição da ação nos moldes do interesse de agir, o que criaria uma diferença injustificada na propositura da ação entre os entes legitimados pela Constituição. No mesmo sentido, Juliano Bernardes rechaça, categoricamente, que possa haver o requisito da pertinência temática, uma vez que se trata de mescla indesejável dos processos de índole objetiva, com sucedâneo de interesse de agir típico dos processos subjetivos, pois não deixaria de se perquirir o interesse subjetivo do legitimado (BERNARDES, Juliano Taveira. Controle Abstrato de Constitucionalidade. Saraiva: São Paulo, 2004, p. 370-371).
}

DiREITOS FundAMENTAIS E E JUSTIÇA - ANO 6, N' 19, P. 50-68, ABR./Jun. 2012 
1 BREVES CONSIDERAÇÕES ACERCA DA ADVOCACIA-GERAL DA UNIÃO NA CONSTITUIÇÃO DE 1988: Função institucional e papel no controle concentrado de constitucionalidade.

Segundo José Afonso da Silva ${ }^{16}$, a Constituição de 1988 inovou com a criação da Advocacia-Geral da União, que deu fim ao bifrontismo característico do Ministério Público Federal pré-88, que antes desempenhava as funções típicas do Ministério Público, cumuladas com a de procuradores federais. Celso Bastos $^{17}$ afirma que esta dúplice função sempre foi alvo de severas críticas doutrinárias, pois se questionava como poderia a mesma instituição exercer, cumulativamente, funções tão díspares, tais como: a de parte desinteressada, na forma de custos legis e, ao mesmo tempo, assumir o interesse de uma das partes em juízo, quando era autora das ações em favor da União.

Na mesma linha de pensamento, Alexandre de Moraes ${ }^{18}$ também aponta como acerto o fato de a Constituição de 1988 ter determinado a criação de uma instituição específica que representa a União judicial e extrajudicialmente, assim como a atividade de consultoria e assessoramento jurídico do Poder Executivo $^{19}$, nos exatos termos do caput do art. 131 da CF/88.

Consoante o disposto no $\S 1^{\circ}$ do art. 131, da CF/88, a escolha para o cargo de Advogado-Geral da União, chefe da Advocacia-Geral da União, será feita livremente pelo Presidente da República dentre cidadãos maiores de trinta e cinco anos, de notável saber jurídico e reputação ilibada. Conforme o advertido por Alexandre de Moraes $^{20}$, tal escolha deve estar calcada, além, logicamente, dos requisitos exigidos pela Constituição, de grande confiança entre o representado (Presidente da República, enquanto chefe do Poder Executivo federal) e representante, apta a justificar a livre escolha. Não se pode olvidar, dentro desse contexto, que o Advogado-Geral da União é considerado Ministro de Estado ${ }^{21}$, portanto, sua atuação está submetida à direta, pessoal e imediata supervisão do Presidente da República (art. $3^{\circ}$, § $1^{\circ}$ da LC 73/93).

Nesse sentido, há de se notar que, por conta de seu perfil institucional designado constitucionalmente, o Advogado-Geral da União não é um órgão dotado de imparcialidade política em suas atuações, na medida em que sua

\footnotetext{
${ }^{16}$ SILVA, op. cit., p. 605.

17 BASTOS, Celso Ribeiro. Curso de Direito Constitucional. 13. ed., São Paulo: Saraiva, 1990, p. 341.

${ }^{19}$ Não obstante as considerações elogiosas ao novo regramento constitucional da representação judicial da União vistas acima, Ronaldo Poletti, op. cit., p. 23, aponta que mesmo essa solução não parece de todo correta, uma vez que a cumulação de defesa jurídica com a de assessoria não se coaduna com o caráter isento e autônomo desta última incumbência, que pode ser contrária aos interesses da União quando se tratar de questões em que for mais importante o resguardo de interesses da República.

${ }^{20}$ MORAES, op. cit., p. 569.

${ }^{21}$ Nesse sentido, cf. parágrafo único, art. 25 da Lei 10.683/2003.
} 
função primordial é a defesa dos interesses da União, o que não significa, logicamente, ações contrárias às disposições constitucionais e instituições jurídicas que o ocupante do cargo jurou defender. Estas considerações ajudam na justificação da livre nomeação do Advogado-Geral da União, que não se limita aos membros das carreiras da Advocacia-Geral da União. Distanciando-se, assim, da figura do Procurador-Geral da República, nomeado pelo Presidente dentre os membros da carreira do Ministério Público da União, por conta de significativas diferenças desempenhadas entre seus múnus constitucionais: o membro do Ministério Público tem como função a defesa da ordem jurídica, do regime democrático e dos interesses sociais e individuais indisponíveis ${ }^{22}$, que podem ser conflitantes com interesses políticos e econômicos, por exemplo, da União. Em arremate, a atuação do PGR não está sujeita ou subordinada à ratificação ou consentimento de nenhum ente político, como, por exemplo, do Presidente da República ${ }^{23}$.

O papel desempenhado pelo AGU no controle de constitucionalidade, desde cedo, provocou inúmeros debates na doutrina, por conta de sua suposta atribuição (de acordo com uma determinada interpretação) de defensor irrestrito do ato impugnado como inconstitucional ${ }^{24}$.

A dogmática constitucional está longe de alcançar unanimidade quanto à questão em debate. Zeno Veloso ${ }^{25}$, por exemplo, atenta que não se pode tomar em consideração o artigo em suas considerações literais, porquanto o múnus constitucional do AGU deve ser condicionado e interpretado de acordo com sua função de garante da Constituição. Em face dessas considerações, o autor pugna pela exclusão do artigo da Constituição.

Por outro lado, Alexandre de Moraes $^{26}$ afirma que o papel do AGU é de curador especial do princípio da presunção da constitucionalidade das leis e atos normativos ${ }^{27}$, não lhe competindo opinar nem exercer a função

\footnotetext{
${ }^{22}$ Art. 127, da CF/88.

${ }^{23}$ No julgamento da ADI 3.289/DF, cujo objeto era Medida Provisória que elevou o Presidente do Banco Central à condição de Ministro de Estado, os ministros do STF levaram em consideração, para julgar improcedente o pedido, a circunstância política da delegação legislativa utilizada pelo presidente (Medidas Provisórias) para regulamentar assunto relativo ao seu interesse, no caso, da estruturação das pastas ministeriais. Portanto, um dos argumentos utilizados pela corte foi a autonomia constitucional do Presidente da República em estruturar institucionalmente seus ministérios, o que, portanto, afastaria a inconstitucionalidade da referida lei no que tange às feições institucionais determinadas pela Lei 10.683/2003 aos cargos ministeriais, como, por exemplo, o de AGU.

${ }_{24}$ De acordo com o art. 103, § $3^{\circ}$ da CF/88: Quando o Supremo Tribunal Federal apreciar a inconstitucionalidade, em tese, de norma legal ou ato normativo, citará, previamente, o Advogado-Geral da União, que defenderá o ato ou texto impugnado. É importante lembrar que não é exigida a defesa do AGU, nos termos do artigo descrito, nos casos de ADI por omissão (ADI 23-QO, Rel. Min. Sydney Sanches, DJ de 01.09.1989; ADI 1.439-MC, Rel. Min. Celso de Mello, DJ de 30.05.2003).

${ }^{25}$ VELOSO, op. cit., p. 92-94

${ }^{26}$ MORAES, op. cit., p. 675-676.

${ }^{27}$ Igualmente pugnando que a curadoria exercida pelo AGU está vinculada à ideia de presunção da constitucionalidade das leis, ver Juliano Bernardes, op. cit., p. 328.
} 
fiscalizadora já atribuída ao Procurador-Geral da República, mas apenas a função eminentemente defensiva, pois, segundo o autor, seria a única justificativa de sua atuação processual nesse caso específico do controle abstrato.

Sem prejuízo de outros autores que trataram do tema, foi Gilmar Mendes ${ }^{28}$ quem teceu as mais acuradas críticas acerca das funções do AGU na fiscalização abstrata de constitucionalidade das leis.

Gilmar Mendes afirma que considerar que o AGU tenha de defender leis que são manifestamente inconstitucionais romperia com um postulado imanente da fidelidade constitucional, uma vez que o AGU realiza juramento de proteger a Constituição. Caso contrário, a Constituição de 1988 teria criado a instituição da Advocacia da Inconstitucionalidade.

De acordo com o referido autor, duas problemáticas contraditórias devem ser levantas quanto às características da intervenção do AGU no processo objetivo concentrado ${ }^{29}$ : a defesa de atos de outros entes federativos que usurparem competência da União e, especialmente, a defesa de atos impugnados pelo próprio Presidente da República.

Quanto à última questão, o autor pondera que uma interpretação há de ser feita para que o AGU não tenha de defender o ato que ele mesmo ajudou a impugnar, enquanto órgão representativo da União e de assessor jurídico do Poder Executivo. Portanto, tendo em vista que o seu papel não é o de advogado da inconstitucionalidade, a atuação da AGU se expressa por meio do exercício de um direito de manifestação, para efeitos de contraditório $^{30}$.

${ }^{28}$ MENDES, Gilmar Ferreira. Controle de Constitucionalidade: aspectos jurídicos e políticos. São Paulo: Saraiva, 1990, p. 260-261.

${ }_{29}$ André Ramos Tavares, por sua vez, considera que o AGU não faz parte do processo objetivo, ainda que a Constituição fale em citação, pois não se trata de ocupar o pólo passivo da ação, mas sim do exercício do contraditório, enquanto função vinculada à ordem pública (TAVARES, André Ramos. Tratado de Argüição de Descumprimento de Preceito Fundamental. São Paulo: Saraiva, 2001, p. 325-326). Trata-se de uma interpretação importante, porque demonstra que a participação do AGU não se confundiria com a de uma posição estática de defensor da constitucionalidade de maneira impensada e automática, mas sim de participação no procedimento para contraditar a demanda. Apesar de discordar-se desta interpretação, pode-se reter a ideia de que, mesmo que esteja escrito no artigo a expressão "citação", não seria a melhor interpretação considerar que o AGU assume uma posição de parte passiva na ADI.

${ }^{30}$ No mesmo sentido se inclina Clermerson Cléve, salientando, inclusive, o curioso caso de o AGU, enquanto órgão que representa, juridicamente, os interesses da União, ter que defender lei estadual que invadiu competências exclusivas da União. Nesse passo, propõe a supressão do referido artigo, por conta da incontrastável antinomia existente entre a função do AGU de guardar a constitucionalidade e probidade dos atos da União e, ao mesmo, tempo, defender os atos inconstitucionais (mesmo de outros estados membros). O autor conclui que o poder de manifestação conferido às autoridades tidas como requeridas na ADI para apresentarem informações acerca do ato objeto da ação direta daria conta do aspecto do contraditório (CLÈVE, Clèmerson Merlin. A Fiscalização Abstrata de Constitucionalidade no Direito Brasileiro. 2. ed., rev. e ampl. São Paulo: Editora Revista dos Tribunais, 2000, p. 181-182). 
Não obstante essas considerações, a jurisprudência inicial do STF acerca do tema era inflexível quanto às funções desempenhadas pelo $\mathrm{AGU}^{31}$. No julgamento da Questão de Ordem na ADI no 97/RO, DJ 30.03.1990, o Ministro Moreira Alves proferiu voto no sentido de que não existia contradição entre o exercício da função do Advogado-Geral da União fixada no caput do art.131 da Carta Magna e o da defesa de norma ou ato atacado na via direta, em tese, como inconstitucional, pois aquele funcionaria como curador especial da constitucionalidade, por conta do princípio da presunção de sua constitucionalidade. De acordo com Moreira Alves, além dos aspectos literais, os aspectos lógicos levavam a crer que no processo objetivo, em que não existem partes nem interesses, não existe confusão nas atuações do AGU, uma vez que a autoridade requerida poderia não exercer a defesa do ato de uma maneira mais correta ou poderia, inclusive, se alinhar com a inconstitucionalidade arguida pelo autor da ação. Por fim, para justificar a compatibilidade da atuação do PGR e do AGU, o ministro relembrara a ideia do curador do vínculo conjugal presente no art. 222 do Código Civil de $1916^{32}$.

O Tribunal, posteriormente, começou a temperar seu entendimento quanto ao papel do AGU na defesa de atos impugnados que violavam consolidada jurisprudência do STF $^{33}$. Conforme o salientado pelo Min. Maurício Correa, a obrigatoriedade de que o AGU defenda todos os atos que são trazidos à fiscalização do Tribunal é desarrazoada, uma vez que o PGR poderá, por vezes, assumir esse papel, quando de suas manifestações. Ademais disso, não poderia o Advogado-Geral da União defender um ato que contraria a interpretação do guardião da Constituição que o mesmo jurou, também, defender.

\section{A REDEFINIÇÃO DO PAPEL DO ADVOGADO-GERAL DA UNIÃO NO CONTROLE CONCENTRADO: O precedente da ADI 3.916/DF.}

Por fim, um recente precedente pode redimensionar o papel da AGU nos processos objetivos da Ação Direta de Inconstitucionalidade. Nos autos da ADI 3.916/DF, DJe 13.05.2010, proposta pelo PGR, da relatoria do

\footnotetext{
${ }^{31}$ ADI 1.350, Rel. Min. Celso de Mello, DJ 04.08.1996. O AGU nem mesmo poderia se posicionar contra ato estadual impugnado, sob pena de frontal descumprimento do munus indisponível que Ihe foi imposto pela própria Constituição da República. De acordo com o último entendimento, cf. ADI 1.254-AgR, Rel. Min. Celso de Mello, Plenário, DJ 19.09.1997.

${ }^{32}$ De acordo com Silvio Venosa, nas ações de nulidade de casamento, nomeava-se curador para defendê-lo. O chamado curador do vínculo conjugal. Por mais desconfortável ou evidente que fosse a hipótese de separação, aquele não poderia deixar de defender o vínculo conjugal. No entanto, a doutrina e jurisprudência afirmavam que o mesmo poderia ser substituído, o que não poderia é ser favorável à dissolução. Não foi previsto no novo código em razão de sua desnecessidade em face da situação da dissolução do vínculo matrimonial atual. Ademais, o Ministério Público, enquanto fiscal da lei, já prestaria as devidas cautelas necessárias em prol da instituição matrimonial (VENOSA, Sílvio de Salvo. Direito Civil: Direito de Família. 7. ed., São Paulo: Atlas, 2007, p. 104-105).

${ }^{33}$ ADI 1.616, Rel. Min. Maurício Corrêa, DJ 24.08.2001.
} 
Min. Eros Grau, questionava-se lei do Distrito Federal decorrente de sua competência estatal, que, supostamente, teria violado competência legislativa da União para dispor acerca da organização da polícia civil do Distrito Federal. A questão de ordem suscitada no julgamento da ação decorreu da manifestação apresentada pelo AGU, que opinou pela procedência do pedido, ou seja, pela inconstitucionalidade da lei.

De acordo com o Min. Marco Aurélio, a atuação do AGU seria dirigida, o que requeria manifestações sempre pela defesa do ato impugnado, porquanto o texto da Constituição seria claro, enquanto preceito imperativo que impõe a defesa da permanência do ato. Quanto ao aspecto da dualidade de funções, relembrou a atuação do PGR, que poderia, como autor da ação, divergir do parecer apresentado como defensor da ordem jurídica. Por fim, salientou que não existiria outra opção interpretativa, porquanto a citação para defesa do ato seria a vontade da Constituição. Quanto aos métodos interpretativos utilizados, o ministro, inicialmente, atestou que estava lançando mão da interpretação literal, todavia, em função dos debates com o Min. Ayres Britto, sustentou que estava interpretando o artigo, também, pelo viés da finalidade e do objetivo da norma, portanto, de maneira teleológica.

O ministro Cezar Peluso buscou outra via interpretativa ao afirmar que poderia existir a diferença de atribuições do AGU na estrutura constitucional, ainda que não tenha sido a melhor escolha político-jurídica, no entanto, tal diferença seria considerada para efeitos de instrução do processo objetivo, uma vez que nele não existiriam partes em um sentido formal. Todavia, ponderou que no caso de usurpação de competências da União, não existiria outro órgão que poderia realizar a defesa dos interesses da União, algo que o AGU não poderia abdicar, porque lhe afastaria de sua função constitucional primordial, mas afirmou, contudo, que o AGU deveria exercer seu papel de contraditor nos demais casos. Por fim, ressaltou que não existiriam sanções constitucionais quanto ao tipo de manifestação que - AGU deveria apresentar ao STF, portanto, inexistiriam mecanismos constitucionais aptos a constrangê-lo a assumir determinada posição contrária a sua convicção jurídica.

Já para o Ministro Ayres Britto, como o Supremo Tribunal Federal atuaria de forma contramajoritária na expulsão de uma lei que foi incorporada no ordenamento jurídico de maneira ortodoxa, ou seja, por meio do normal funcionamento democrático, e a mesma correria o risco de ser expulsa pela via jurisdicional ${ }^{34}$, a Constituição previra a defesa do ato pelo AGU como uma sobrecautela. Dessa forma, de acordo com o ministro, com base em uma interpretação teleológica e sistemática ${ }^{35}$, seria uma deferência à separação dos poderes.

\footnotetext{
${ }^{34}$ Obviamente, entendida pelo ministro como uma via anormal, ainda que disposta institucionalmente na própria Constituição.

${ }^{35}$ Como se pode observar, os Ministros se preocuparam em fundamentar suas interpretações com base nos chamados métodos interpretativos, como se fossem um argumento de reforço às
} 
Todavia, encabeçado pelo Min. Gilmar Mendes, o Tribunal entendeu que a CF/88 concedeu ao AGU o direito de manifestação. A fundamentação foi a de que o órgão se colocaria em situação contraditória e desconfortável ao defender um ato contrário ao interesse da União, vulnerando sua função primordial de defensor dos seus interesses (CF/88, art. 131). Ademais, as defesas dos atos impugnados, para fins de realização de um possível contraditório, deveriam ser feitas pelos agentes requeridos na ação. Como podemos constatar, o ministro Gilmar Mendes apenas reiterou suas considerações teóricas expostas acima sobre o tema.

\section{ANÁLISE TEÓRICA DOS VOTOS DA QO NA ADI 3.916/DF}

Existe uma significativa diferença entre leis e a Constituição: a última serve de fundamento para as primeiras, portanto, a interpretação dada às normas constitucionais deve ser, igualmente, fundamental. Tais interpretações devem se ajustar às disposições mais básicas do poder político da comunidade e deve ser possível sempre justificá-las ${ }^{36}$. No caso em comento, é imperativo que as fundamentações presentes nos votos dos ministros se ajustem e possam ser consideradas como as melhores justificativas sobre a definição institucional do papel da AGU. Com base em tal premissa, os votos dos ministros serão analisados para que possamos aferir quais argumentos satisfazem os testes do ajuste e da justificação.

No caso da interpretação constitucional, e, mais importante, no caso do art. 103, § $3^{\circ}$ da CF/88, os ministros estão de acordo com o que as palavras do texto expressam, enquanto fase pré-interpretativa, no entanto, divergem quanto às normas que podem ser extraídas delas e de sua adequação ao caso a ser julgado. Em muitos casos perante o Tribunal, os juízes constitucionais estão de acordo com aquilo que compõe o texto normativo, dentro de um acordo pré-interpretativo ${ }^{37}$, ou seja, semanticamente, todos os

justificativas apresentadas. Além de não desempenharem tal papel, os métodos não podem ser considerados como argumentos independentes, uma vez que os ministros concordaram quanto aos métodos utilizados (especialmente: literal, sistemático e teleológico), mas discordavam, não apenas quanto ao conteúdo a ser extraído do método, mas discordavam, principalmente, quanto ao resultado da interpretação determinada, supostamente, pelo método de escolha. De nada serviu, portanto, a utilização de métodos na interpretação.

${ }_{36}$ DWORKIN, Ronald. O Império do Direito. Tradução de Jefferson Luiz Camargo. São Paulo: Martins Fontes, 1999, p. 455.

37 De acordo com Dworkin (Ibid. 1999, p. 81-84), para que enfatize um refinamento da interpretação construtiva, o autor elenca as seguintes etapas que caracterizam o ato de interpretar: A) Pré interpretativa: necessidade de consenso entre os intérpretes, etapa em que se expõe as regras e padrões que se consideram fornecer o conteúdo experimental da prática; B) Interpretativa: Concentração numa justificativa geral para os principais elementos da prática identificada na etapa pré-interpretativa - intérprete atua como autor da interpretação, não da prática e C) Pós interpretativa: ajustamento da sua ideia daquilo que a prática realmente requer para melhor servir à justificativa que ele aceita na prática interpretativa. A interpretação de uma prática social exige, portanto, o equilíbrio entra a justificativa da prática e suas exigências pós-interpretativas. Desta forma, não haveria atividade interpretativa se os membros da comunidade compartilhassem, ao menos de maneira aproximada, as mesmas hipóteses a seu respeito. 
juízes estão de acordo com as palavras (e seus significados isolados) que compõem o texto constitucional, no entanto, divergem quanto ao resultado da sua interpretação. Em outras palavras, divergem quanto às normas que podem ser extraídas do texto, já na fase pós-interpretativa. Isto quer dizer que os juízes constitucionais divergem sobre o conteúdo das normas, tomando em consideração as justificativas que formulam como suas intenções, e tais justificativas devem ser aquelas que se fundamentam em uma teoria interpretativa acerca da teoria da Constituição e do que pode ser considerado como a melhor leitura de suas normas.

Ora, tal compreensão acerca do dissenso entre juízes constitucionais é facilmente verificada na prática do Supremo Tribunal Federal, especialmente no caso do papel do AGU no controle concentrado de constitucionalidade. É inconcebível acreditar que nossos ministros divirjam quanto à semântica das palavras que compõem determinado texto normativo ${ }^{38}$ (ou que divirjam quanto aos fatos em questão, em contraste com as teorias positivistas), mas é factível crer que divirjam quanto à norma a ser extraída da interpretação/ aplicação.

No caso do art. 103, § $3^{\circ}$ da CF/88, é patente, de acordo com a síntese dos argumentos exposta na seção anterior, que todos os ministros concordam com o significado das palavras que compõem o parágrafo, mas, mesmo com a aparente clareza semântica do texto normativo constitucional, seu contexto demonstra que uma interpretação simplesmente literal não seria a mais adequada com outros princípios interpretativos substantivos que são amparados pela mesma Constituição ${ }^{39}$.

Neste ponto, podemos afirmar que os argumentos do Min. Marco Aurélio não se esgotam, simplesmente, na defesa da "literalidade" do texto constitucional. Suas interpretações revelam uma compreensão mais ampla sobre o papel da vontade dos constituintes na interpretação constitucional, e, por fim, do AGU. Entretanto, o argumento da vontade da Constituição, por exemplo, conduz, inevitavelmente, a considerações a respeito da intenção

${ }^{38}$ Cass Sunstein aponta que existem duas espécies de princípios interpretativos que regem a interpretação de um texto, inclusive o constitucional: os princípios interpretativos semânticos e substantivos. O primeiro se relaciona com a fala em seu sentido simples e pode ser confirmado no dicionário, ou seja, no sentido comum das palavras. Algumas provisões da Constituição são semânticas (o presidente tem que ter, no mínimo, 35 anos, p. ex.) os princípios substantivos não necessitam de uma aula de linguagem ou de um dicionário, mas de justificações políticas substantivas e a seleção de princípios substantivos deve ser feita com base em assunções morais e políticas (SUNSTEIN, Cass. The Partial Constitution. Cambridge: Harvard University Press, 1994, p. 101-102)

39 Mesmo que um termo seja claro em abstrato ou no dicionário, a incerteza na sua interpretação pode surgir por conta da cultura e do contexto. Nesse sentido, mesmo os mais aparentes, claros, precisos e específicos termos podem se tornar incertos por conta de nossa impossibilidade de prever o futuro e de como eventos posteriores afetarão a compreensão presente; mais cedo ou mais tarde, a linguagem clara confrontará um problema não antecipado pela formulação legislativa (SUNSTEIN, Cass. Legal Reasoning and Political Conflitct. New York: Oxford University Press, 1996, p. 122-125). 
dos constituintes, ou seja, sobre o que os membros da assembleia constituinte pretendiam quando acrescentaram o referido dispositivo constitucional determinando a citação do AGU para a defesa do ato impugnado ${ }^{40}$.

Todavia, esta argumentação é fraca e impossível de ser defendida, pois a busca por uma intenção unitária dos constituintes com base em argumentos históricos, analíticos e psicológicos não pode prosperar, porque se baseia no erro de crer que a intenção dos constituintes é um fato isolado esperando para ser encontrada. Ademais, não existem razões plausíveis para a construção e sustentação de uma teoria que afirme quais intenções devem ser consideradas importantes ou quais estados mentais dos constituintes devem ser considerados, em função de inúmeros fatores: impossibilidade de determinar a intenção de qual dos constituintes se levará em conta; dificuldade em determinar se devemos considerar os desejos e expectativas do parlamentar na interpretação da Constituição; a necessidade de que sempre o parlamentar justifique suas decisões, no caso de negativas ou delegações, quanto a determinados direitos e, caso fosse possível desvendar uma intenção constituinte, ainda permanecerá o questionamento de decidir se a mesma é relevante para a resolução dos problemas constitucionais do presente ${ }^{41}$.

No mesmo sentido, a ideia de que a regra constitucional é "clara"42 apresenta muitas controvérsias. A interpretação textual é parte essencial de

\footnotetext{
40 Tendo em vista que as teorias que afirmam a possibilidade de as normas constitucionais serem claras, confirmando uma posição jurídica apenas pela análise semântica, consideram que sua divergência com a teoria oposta está em franca e genuína divergência, estas devem ter razões que julgam suficientes para defender sua tese. Nesse passo, para não incorrer em petição de princípio, os argumentos daqueles que defendem uma interpretação literal devem ir além do texto constitucional: devem basear o argumento da literalidade em preceitos de uma moralidade política, e nunca poderão limitar-se à simples afirmação de que aquela é a melhor interpretação de um texto, porque no texto não consta nenhum dispositivo determinando que assim se proceda (DWORKIN. Uma Questão de Princípio. Tradução de Luís Carlos Borges, São Paulo: Martins Fontes, 2005, p. 46).

${ }^{41}$ DWORKIN, Ibid, p. 50-80.

42 No caso do direito, é algo inevitável, por conta dos objetivos desta criação cultural, que o intérprete valorize mais o sentido correto, do que uma forma canônica de exposição da lei. De mais a mais, devemos interpretar, primeiramente, o que se entende como canônico num texto, para falarmos sobre seu desrespeito ou que ele é claro ou obscuro (Idem, Ibid, p. 223). Não apenas isso, mas o significado das leis não se esgota no momento e nem sempre terá a mesma interpretação, determinando que apenas uma interpretação constituinte ou primeva seja a mais correta desde sempre. Mesmo porque, ainda que exista isomorfia entre as expressões de uma lei com o sentido comum a elas empregado, será necessária a interpretação, uma vez que estas podem assumir sentidos diversos na linguagem jurídica, portanto, a suposta clareza de uma lei não é uma premissa, mas o resultado da interpretação, na medida em que apenas se pode afirmar que a lei é clara após ter sido interpretada. O texto claro pode se tornar obscuro em função da tensão dos interesses que se põem em torno dele, travando-se uma luta pela produção de um sentido que melhor responda aos anseios do intérprete em face do problema a ser resolvido (GRAU, Eros Roberto. Ensaio sobre a Interpretação/aplicação do Direito. 2. ed., São Paulo: Malheiros, 2003, p. 70). Um dos casos mais emblemáticos sobre a questão é o do inciso $\mathrm{XI}$, art. $5^{\circ}$ da CRFB/88 (a casa é asilo inviolável do indivíduo, ninguém nela podendo penetrar sem consentimento do morador, salvo em caso de flagrante delito ou desastre, ou para prestar socorro, ou, durante o dia, por determinação judicial). A jurisprudência do STF, apesar
} 
qualquer programa mais amplo de interpretação constitucional, pois o que foi realmente afirmado pelos constituintes é sempre, no mínimo, um componente importante para qualquer argumentação constitucional que se pretenda verdadeiramente interpretativa. No entanto, não significa uma infidelidade à Constituição e ao seu texto normativo se adotamos uma interpretação diferente do que poderia significar as palavras de uma norma constitucional, apenas num plano semântico, sem que, antes, determinemos seu melhor sentido.

Temos um texto constitucional. Não discordamos sobre o conjunto de enunciados que constituem este texto e ninguém questiona sua sequência de letras e espaços que dão a forma que tem, portanto identificar uma série canônica de letras e espaços é apenas o começo da interpretação, uma vez que permanece o problema de saber o que significa qualquer segmento específico de tal série e uma interpretação apenas será infiel com a instrução sobre o que uma norma constitucional significa quando, depois de feita a melhor interpretação dela, for a ela contrária ${ }^{43}$. Nesse sentido, apenas podemos dizer que a regra constitucional é clara ou que veda a livre manifestação do AGU, como resultado da interpretação do texto normativo constitucional, nunca como seu ponto de partida.

Portanto, com base na jurisprudência do STF e das afirmações doutrinárias, uma simples interpretação literal do dispositivo não corresponde às expectativas de uma interpretação da prática do controle de constitucionalidade, pois é impossível afirmar com segurança que os constituintes queriam que o AGU defendesse todos os atos impugnados como inconstitucionais ou que esta seja a melhor interpretação do seu papel político, tendo em vista que assume uma posição subordinada aos interesses da União. De mais a mais, sua posição como Ministro de Estado, demissível ad nutum, impede que qualquer analogia com o papel do PGR seja sustentada. Do exposto, a interpretação feita pelo Min. Marco Aurélio não apresenta uma forte justificativa, na medida em que se limitou a argumentos semânticos e pouco substanciais.

Quanto ao argumento do Min. Ayres Britto, ainda que esteja ancorado em princípios interpretativos substantivos que apóiam sua tese de que o artigo deve ser considerado em sua literalidade (quais sejam: a de que a opção constitucional foi criar uma sobrecautela quanto a exclusão heterodoxa de uma norma pela via jurisdicional, em contraposição a sua origem democrática determinada pela inserção parlamentar), não parece prosperar ante um cotejo da sistemática do controle de constitucionalidade exercido em nosso país.

da aparente "clareza" do termo "casa", sedimentou que, para os fins da proteção jurídica a que se refere o inciso, o conceito normativo de 'casa' revela-se abrangente e, por estender-se a qualquer aposento de habitação coletiva, desde que ocupado (CP, art. 150, $\S 4^{\circ}$, II), compreende, por exemplo, os quartos de hotel (RHC 90.376, Celso de Mello, DJ 18.05.2007).

${ }^{43}$ DWORKIN, Ronald. A Justiça de Toga. Trad. Jefferson Luiz Camargo, São Paulo: Martins Fontes, 2010, p. 171. 
Como nosso sistema de controle de constitucionalidade é integralmente difuso ${ }^{44}$, uma vez que todo o poder judiciário é competente para realizar o controle de constitucionalidade das leis e o STF não detém o monopólio da declaração da inconstitucionalidade da lei, devemos considerar que os princípios de moralidade política que sustentam tal prática (o da supremacia da constituição ${ }^{45}$ e da democracia) não são vistos sob sua melhor luz, caso consideremos que, apenas no julgamento da ADI (lembremos que o AGU não age na $A D C$, nem na ADI por omissão e na ADPF sua atuação é facultativa e restrita ao âmbito cautelar ${ }^{46}$ ) a Constituição exija uma cautela superior em detrimento aos demais meios jurisdicionais, pois a impugnação de uma lei pode ser feita no bojo de qualquer processo, em qualquer instância, sem que seja necessária (para que o juiz considere a nulidade da norma infraconstitucional) a manifestação de membros das procuradorias estaduais ou federais, no intuito de defendê-las ${ }^{47}$. Não podemos olvidar que o STF pode declarar a inconstitucionalidade de uma lei, incidentalmente, sem que ocorra a defesa irrestrita e desmedida do ato pelo AGU em um recurso extraordinário $^{48}$, por exemplo, ou quando julga improcedente uma ADC. Sendo assim, as considerações do Min. Ayres Britto não são suficientes para justificar, de maneira substantiva, sua interpretação do dispositivo.

44 Para detalhes dessas considerações e classificações dos sistemas de controle de constitucionalidade, ver PEGORARO, Lucio. La Justicia Constitucional: Una perspectiva comparada. Madrid: Dykinson, 2004 e MAUÉS, Antonio G. Moreira. O Controle de Constitucionalidade das Leis no Brasil como um Sistema Plural. Pensar, Fortaleza, v. 15, nº 2, jul./dez., p. 356-384, 2010. ${ }^{45}$ Eduardo Enterría afirma que a ideia de um direito fundamental, de uma Higher Law, é tributária do direito natural, como superior ao direito positivo, sendo o primeiro inderrogável e superior ao último. Os direitos naturais passam a ser o último teste de validez das leis positivas. Esta assertiva determina uma conclusão importante: a de que o juiz pode controlar os atos do parlamento, ou seja, a possibilidade de se plasmar em uma Constituição escrita esse parâmetro normativo superior que decide a validade das leis do parlamento. O que faz desaparecer a noção de soberania do parlamento, uma vez que não pode produzir atos legislativos livremente, mas, ainda que assim o fosse, por conta de ser um documento escrito, sua proteção não seria completa sem o controle de constitucionalidade. Por ser uma norma fundamental, a vinculação dos juízes com a Constituição é maior do que com as leis ordinárias (ENTERRÍA, Eduardo Garcia de. La Constituición como Norma y el Tribunal Constitucional. 3. ed., Madrid: Editorial Civitas, 1985, p. 51-53).

${ }^{46}$ Art. 50: O Supremo Tribunal Federal, por decisão da maioria absoluta de seus membros, poderá deferir pedido de medida liminar na arguição de descumprimento de preceito fundamental; $\S 2^{\circ} \mathrm{O}$ relator poderá ouvir os órgãos ou autoridades responsáveis pelo ato questionado, bem como o Advogado-Geral da União ou o Procurador-Geral da República, no prazo comum de cinco dias.

${ }^{47}$ Ainda que se argumente que no controle difuso o juiz não expurga a lei do ordenamento, mas apenas afasta sua aplicação ao caso concreto, devemos lembrar que o argumento do Ministro Ayres Britto estava focado nas consequências democráticas do controle da constitucionalidade da lei, ou seja, pelo fato do Poder Judiciário interferir na produção legislativa do Congresso. Mesmo no controle difuso a lei é considerada contrária à Constituição, ou seja, o ato democrático inserido pelo Legislativo é afastado por um poder contramojoritário. O problema principal da crítica do Ministro permanece.

${ }^{48}$ O STF pode declarar a inconstitucionalidade de uma lei via Recurso Extraordinário sob o regime da Repercussão Geral e, logo em seguida, editar Súmula Vinculante. 
O Min. Cezar Peluso, por fim, postulou que a inexistência de constrangimentos constitucionais indicava a liberdade do AGU em apresentar manifestações no sentido que the aprouvesse. Não precisamos de um maior esforço argumentativo para demonstrar que o ministro considerou que o AGU não possui um dever de defender o ato impugnado, porque a Constituição não imputou nenhuma sanção ao seu descumprimento. Tal construção argumentativa está baseada na compreensão kelseniana ${ }^{49}$ de direito, segundo a qual a existência de um dever está, prejudicialmente, ligada à existência de uma sanção ${ }^{50}$.

Em desacordo com o esposado pelo ministro, desde Hart ${ }^{51}$ a existência de uma sanção não confirma, necessariamente, a existência do direito (no caso discutido, de um dever jurídico). De acordo com Hart, uma lei criminal ou que imponha a responsabilidade civil a determinado indivíduo se contrapõe às leis que determinam a feitura e a realização de um contrato, porquanto as últimas não impõem deveres e obrigações semelhantes às primeiras para as partes contratantes. Dessa feita, é curial que se considere o caráter relativo à função social da lei para que lhe se diferencie das demais, como uma lei penal e uma civil, por exemplo. Por fim, as leis criminais determinam um comportamento indesejado pela sociedade, por isso são impostas graves sanções punitivas ao infrator. No caso das leis civis que regulamentam determinadas condutas, ainda que seja possível a nulidade do ato que exterioriza a conduta em razão de alguma irregularidade formal ou material, esta é encorajada e prevista pela lei (HART, 1986, p. 40-89).

Não bastasse tal argumento, outro ponto precisa ser rebatido no argumento do Min. Peluso, qual seja: o de que a manifestação do AGU pode ser livre, ainda que a Constituição determine o contrário. Ora, isto quer dizer que o AGU estaria descumprindo a Constituição todas as vezes em que se manifestasse pela inconstitucionalidade do ato, pois, por conta de um equívoco técnico, a Constituição não impunha sanções à atitude inconstitucional. O Ministro ignora que é a mesma Constituição que define o AGU como representante dos interesses da União, portanto, quando o AGU não desempenha tal função (por exemplo, quando defende um ato contrário aos interesses da União), também estaria, de acordo com os argumentos de Peluso, descumprindo a Constituição e o Ministro não demonstra porque uma função deve ser considerada superior ou mais importante que a outra. Dessa forma, não nos parece que o argumento da não existência de sanção seja forte o suficiente para justificar esta interpretação das funções do AGU.

${ }^{49}$ KELSEN, Hans. Teoria Pura do Direito. Trad. João Batista Machado, 7. ed., São Paulo: Martins Fontes, 2006.

50 Segundo Kelsen, "se o direito é concebido como ordem coercitiva, uma conduta apenas pode ser considerada como objetivamente prescrita pelo Direito e, portanto como conteúdo de dever jurídico, se uma norma jurídica liga à conduta oposta um ato coercitivo como sanção". KELSEN, Hans. Ob. Cit., p. 128-129.

${ }^{51}$ HART, Herbert L. A. O Conceito de Direito. Tradução de A. Ribeiro Mendes, Lisboa: Fundação Calouste Gulbenkian, 1986. 


\section{CONSIDERAÇÕES CONCLUSIVAS}

A Constituição, assim como a legislação infraconstitucional, devotou um papel institucional para o Advogado-Geral da União: defender os interesses da União, enquanto Ministro de Estado livremente nomeado pelo Presidente da República, para que possa desenvolver seu principal mister constitucional da melhor forma possível. Ora, alçar o AGU ao status de Ministro de Estado representa uma escolha política constitucional, reforçada em legislações posteriores, que demonstra que sua função desempenhada na República não pode ser equiparada àquela, por exemplo, do Procurador-Geral da República. O perfil institucional do AGU é assegurar que os interesses de seu representante (que lhe devotou confiança no ato de sua nomeação ${ }^{52}$ ) sejam atendidos em seu benefício ${ }^{53}$.

Por outro lado, defender uma possível cisão no papel institucional do AGU é pouco coerente com tais considerações. Os princípios que fundamentam a atuação do PGR são totalmente diferentes daqueles que fundamentam a existência constitucional do AGU, uma vez que o PGR possui autonomia para, mesmo propondo a ação, opinar pela sua improcedência, na medida em que não possui vínculo político de responsabilidade perante nenhuma entidade política, assim como não está subordinado aos comandos presidenciais. Portanto, sustentar a possibilidade de ação dúplice do AGU em analogia ao PGR parece, igualmente, desmedida. Ademais, defender a atuação dúplice do AGU, no caso, seria repristinar a antiga cumulação indevida de funções do Ministério Público Federal que deu origem, justamente, às carreiras da Advocacia-Geral da União, uma vez que não se trataria de cumulação de atividades concorrentes dentro de uma mesma, e coerente, perspectiva institucional, tal como o PGR (se o PGR opina pela improcedência da ADI que propôs, ele não age defendendo interesses de algum Poder da República), mas de cumulação de atividades em que interesses políticos e institucionais, completamente, distintos estão em jogo ${ }^{54}$.

Conforme o apontado acima por Gilmar Mendes, a interpretação de que o AGU deve defender todo e qualquer ato considerado inconstitucional poderia levar-Ihe a esposar posições contraditórias aos interesses da União. Portanto, para fundamentar a tese da simples manifestação ${ }^{55}$ como a que melhor justifica o papel do AGU, lançamos mão do princípio constitucional da

\footnotetext{
${ }^{52}$ Vale salientar, justamente por conta do acento político em sua escolha, que a nomeação do AGU não passa pelo referendo senatorial, como ocorre com as indicações ao cargo de PGR, sendo demissível ad nutum.

${ }^{53}$ Manoel Gonçalves Ferreira Filho afirma que o papel político dos ministros é de auxiliar o chefe do governo, ou seja, atuam como vogais do governo (FERREIRA FILHO, Manoel Gonçalves. Curso de Direito Constitucional. 18. ed., São Paulo: Saraiva, 1990, p. 195).

${ }^{54}$ No caso de ADI proposta com fundamento na usurpação de competências da União, por exemplo.

${ }^{55}$ Conforme dispõe, aliás, a Lei 9.868/99 (Art. $8^{\circ}$ Decorrido o prazo das informações, serão ouvidos, sucessivamente, o Advogado-Geral da União e o Procurador-Geral da República, que deverão manifestar-se, cada qual, no prazo de quinze dias).
} 
correção funcional ${ }^{56}$, segundo o qual a interpretação da norma constitucional não pode levar o intérprete a resultados que perturbem o esquema organizatório-funcional estabelecido pela Constituição ${ }^{57}$, daí porque devemos adotar uma interpretação do papel do AGU que atribua ao texto constitucional a melhor compreensão possível do que as normas constitucionais que regem suas competências determinam, a fim de se coadunar com a melhor forma de se apresentar a prática do controle de constitucionalidade em nosso país.

Portanto, o AGU se configura como um órgão governamental que defende, antes de tudo, a higidez da Constituição e oficia nos processos objetivos de controle de constitucionalidade como sujeito processual autônomo ("autônomo" no sentido de que sua manifestação não estará sempre vinculada à defesa da constitucionalidade do ato impugnado, não "autônomo" no sentido de uma ausência de subordinação ao Presidente da República), designado pela Constituição para apresentar argumentos jurídicos e políticos que sirvam de auxílio às ponderações dos Ministros, considerando que tais argumentos poderiam revelar interesses da União importantes no julgamento da causa ${ }^{58}$.

\section{BIBLIOGRAFIA}

BASTOS, Celso Ribeiro. Curso de Direito Constitucional. 13. ed., São Paulo: Saraiva, 1990.

BERNARDES, Juliano Taveira. Controle Abstrato de Constitucionalidade. São Paulo: Saraiva, 2004.

\footnotetext{
${ }^{56}$ A referência ao sobredito princípio é mais argumentativa do que sobre teoria da interpretação, uma vez que discordamos frontalmente das considerações acerca da interpretação constitucional dividida em métodos que se inter-relacionam e de princípios que podem interagir de forma conjunta, de acordo com Virgílio Afonso da Silva (SILVA, Virgílio Afonso da. Interpretação Constitucional e Sincretismo Metodológico. In: Virgílio Afonso da Silva. (Org.). Interpretação Constitucional. São Paulo: Malheiros, 2005)

${ }^{57}$ COELHO, Inocêncio Mártires. Interpretação Constitucional. 3. ed., São Paulo: Saraiva, 2007, p. 104.

58 Em recentes decisões (ADI 2.376/RJ, DJe 01.07.2011; ADI 3.413/RJ, DJe 01.08.2011 e ADI 2.906/RJ, DJe 29.08.2011), constatam-se ementas de julgados do STF que contêm a seguinte assertiva: consoante dispõe a norma imperativa do § $3^{\circ}$ do artigo 103 da Constituição Federal, incumbe ao Advogado-Geral da União a defesa do ato ou texto impugnado na ação direta de inconstitucionalidade, não lhe cabendo emissão de simples parecer, a ponto de vir a concluir pela pecha de inconstitucionalidade. À primeira vista, poderia parecer que o tribunal reviu seu posicionamento sobre o tema, no entanto, analisando o inteiro conteúdo do acordão podemos notar algumas questões: 1 ) todos os três julgados ementados daquela forma foram relatados pelo Min. Marco Aurélio, voto vencido na ADI 3.916/DF; 2) em todos os casos não houve nenhuma manifestação de qualquer ministro sobre o tema, ou seja, não expressaram concordância ou discordância sobre o voto do Min. Marco Aurélio e 3) na parte dispositiva do acórdão não constam determinações sobre o papel do AGU ou sobre a remessa do processo para que o mesmo ajuste sua manifestação. Com efeito, apesar de constar na ementa, o que, por si só, não significa muita coisa, na medida em que a ementa não possui valor jurídico nenhum, não se pode considerar que o STF tenha alterado o entendimento da ADI 3.916/DF, uma vez que não houve debates aprofundados sobre o tema ou pronunciamentos formais sobre o ponto, tal qual a decisão na Questão de Ordem ora analisada. Tratam-se, portanto, de posicionamentos isolados do Min. Marco Aurélio que constam nas ementas por ele redigidas, que não expressam a compreensão da corte.
} 
BONAVIDES. Paulo. Curso de Direito Constitucional. 11. ed., São Paulo: Malheiros, 2001.

CAPPELLETTI, Mauro. O Controle Judicial de Constitucionalidade das Leis no Direito Comparado. Porto Alegre: SAFE, 1992.

COELHO, Inocêncio Mártires. Interpretação Constitucional. 3. ed., São Paulo: Saraiva, 2007.

CLÈVE, Clèmerson Merlin. A Fiscalização Abstrata de Constitucionalidade no Direito Brasileiro. 2. ed., rev. e ampl. São Paulo: Editora Revista dos Tribunais, 2000.

DWORKIN, Ronald. A Justiça de Toga. Trad. Jefferson Luiz Camargo, São Paulo: Martins Fontes, 2010.

Uma Questão de Princípio. Tradução de Luís Carlos Borges, São Paulo:

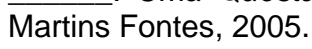

. O Império do Direito. Tradução de Jefferson Luiz Camargo, São Paulo: Martins Fontes, 1999.

ENTERRÍA, Eduardo Garcia de. La Constituición como Norma y el Tribunal Constitucional. 3. ed., Madrid: Editorial Civitas, 1985.

FERREIRA FILHO, Manoel Gonçalves. Curso de Direito Constitucional. 18. ed., São Paulo: Saraiva, 1990.

GRAU, Eros Roberto. Ensaio sobre a Interpretação/Aplicação do Direito. 2. ed., São Paulo: Malheiros, 2003.

HART, Herbert L. A. O Conceito de Direito. Tradução de A. Ribeiro Mendes, Lisboa: Fundação Calouste Gulbenkian, 1986.

KELSEN, Hans. Jurisdição Constitucional. 2. ed., São Paulo: Martins Fontes, 2007. Teoria Pura do Direito. Trad. João Batista Machado, 7. ed., São Paulo:

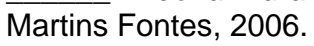

LEAL, Victor Nunes. Problemas de Direito Público e outros Problemas. Brasília: Ministério da Justiça, 1997.

LEWANDOWSKI, Enrique Ricardo. Pressupostos Materiais e Formais da Intervenção Federal no Brasil. São Paulo: Saraiva, 1994.

MAGALHÃES, Breno Baía. Em Defesa da Convergência dos Sistemas de Controle de Constitucionalidade: aspectos materiais. Revista de Direito Constitucional e Internacional, v. 79, São Paulo, abr./jun., 2012.

MAUÉS, Antonio G. Moreira. O Controle de Constitucionalidade das Leis no Brasil como um Sistema Plural. Pensar, Fortaleza, v. 15, nº 2, jul./dez., 2010, p. 356-384.

MENDES, Gilmar Ferreira. Controle de Constitucionalidade: aspectos jurídicos e políticos. São Paulo: Saraiva, 1990.

Jurisdição Constitucional. 5. ed., São Paulo: Saraiva, 2005.

MORAES, Alexandre de. Direito Constitucional. 18. ed., São Paulo: Atlas, 2005.

PEGORARO, Lucio. La Justicia Constitucional: Una perspectiva comparada. Madrid: Dykinson, 2004.

POLETTI, Ronaldo Rebello de Britto. Controle da Constitucionalidade das Leis. 2. ed., Rio de Janeiro: Forense, 1995. 
SILVA, José Afonso da. Curso de Direito Constitucional Positivo. 26. ed., São Paulo: Malheiros, 2006.

SILVA, Virgílio Afonso da. Interpretação Constitucional e Sincretismo Metodológico. In: Virgílio Afonso da Silva. (Org.). Interpretação Constitucional. São Paulo: Malheiros, 2005.

STRECK, Lenio Luis. Jurisdição Constitucional e Hermenêutica. Rio de Janeiro: Forense, 2002.

SUNSTEIN, Cass. Legal Reasoning and Political Conflitct. New York: Oxford University Press, 1996.

. The Partial Constitution. Cambridge: Harvard University Press, 1994.

TAVARES, André Ramos. Tratado de Argüição de Descumprimento de Preceito Fundamental. São Paulo: Saraiva, 2001.

VELOSO, Zeno. Controle Jurisdicional de Constitucionalidade. 3. ed., Belo Horizonte: Del Rey, 2003.

VENOSA, Sílvio de Salvo. Direito Civil: Direito de Família. 7. ed., São Paulo: Atlas, 2007. 